\title{
迹国 \\ The Mediating Role of Corporate Social Responsibility (CSR) Disclosure on Good Corporate Governance (GCG) and Firm Value
}

\author{
Saparila Worokinasih $^{1}$ and Muhammad Lutfi Zuhdi bin Mohamad Zaini ${ }^{2}$
}

\begin{abstract}
The application of Good Corporate Governance (GCG) and Corporate Social Responsibility (CSR) disclosure is one way to increase company value by focusing on the balance of internal and external interests. This study aim is to determine the effect of GCG and CSR disclosure on company value. This type of research is explanatory research with a quantitative approach, using a sample of 13 mining companies listed on the Indonesia Stock Exchange. By using Partial Least Square (PLS) technique, the result showed that (1) Good Corporate Governance has a significant and positive effect on Corporate Value ( -value $=0,000 ; \alpha=5 \%$ ); (2) Good Corporate Governance has a significant and negative effect on Corporate Social Responsibility Disclosure ( $p$-value $=0,000 ; \alpha=5 \%$ ); (3) Corporate Social Responsibility Disclosure has not had a significant effect on Corporate Value ( $p$-value $=0.875 ; \alpha=5 \%)$.
\end{abstract}

JEL classification: $\mathrm{G} 12, \mathrm{G} 34$

Keywords: Good Corporate Governance, Corporate Social Responsibility, Firm Value

\footnotetext{
${ }^{1}$ Department of Business Administration, Universitas Brawijaya, Malang, Indonesia. saparila.fia@ub.ac.id

${ }^{2}$ School of Government, COLGIS, Universiti Utara Malaysia, Sintok, Malaysia
} 


\section{INTRODUCTION}

The long- term objective a company is to maximise the value of the corporation (Husnan, 2006). Investors will analyse the company's stock price and used the data in order to decide whether they will participate in investing in that company. This is because the value of the company reflects the amount of trust that other people have towards that company. The higher the value of the company reflects the good management and the perceived future prospects, so that investors believe that with high company value they will get the desired rate of return (Widyasari, 2013).

To achieve the high value, cannot only focus on maximising the profits, but the company also needs to pay attention to the internal and external interests of the stakeholders. The mechanism of Good Corporate Governance (GCG) and the disclosure of Corporate Social Responsibility (CSR) are important factors that can increase the value of the company by taking into account the balance between internal and external interests of the company. According to Sutedi (2012) related to agency theory, GCG emerged as a solution to agency problems. Implementation of GCG with several principles, namely: transparency, accountability, responsibility, independence and fairness principles (Hair, Hult, Ringle, $\&$ Sarstedt, 2016), provide very effective protection towards the company's stakeholders so that they will be convinced.

Indonesia starts implementing Good Corporate Governance system since signing a Letter of Intent with the International Monetary Fund (IMF) (Sutedi, 2012). Along with this, Komite Nasional Kebijakan Corporate Governance (KNKCG,2016) believes that every company in Indonesia are obliged to implement the CGC standard that is applied at the international level. According to a survey that was conducted by the Asian Corporate Governance Association (ACGA), it shows that Indonesia was ranked $11^{\text {th }}$ in the field of Good Corporate Governance (GCG), after China and the Philippines. The low scores of GCG implementation in Indonesia indicates that most companies in Indonesia still have a low understanding of the importance of implementing GCG.

Meanwhile, the efforts to maximise the value of the company also cannot be separated from the environment and the community within the company. The company also expected to run a healthy business, not only just focusing on the interests of the company but also pay attention to ethical values in business. Corporate Social Responsibility has a positive relationship with the values of the company. If the company has a very good social performance and very good environment, it will receive a positive response from the investors through the increasing of the company's stock price (Gerianta, 2013).

Corporate Social Responsibility (CSR) in Indonesia today is no longer voluntary, but is mandatory for some companies to implement it. This is regulated in Article 74 of Limited Liability Company Law No. 40/2007. Furthermore, the company also should disclose the implementation of CSR of their company activities in a report called by sustainability report. A sustainability report is a form of publication by the company that relates to programmes that have been held by the company.

The Global Reporting Initiatives (GRI) standard is a guideline for making sustainability reports that represents the best practices globally in economic reports, environmental and 
social impacts to the public. The GRI Guidelines (GRI, 2013) report was published in 2006 and continues to be developed and perfected until the year 2013, where the latest GRI guidelines, which is GRI 14, was published. This guideline consists of 6 indicators, which are economic performance, environmental performance, and social performance consisting of employment, human rights, society, and product responsibilities.

There are few numbers of previous studies on the effects of GCG and CSR on the company values that resulted in mixed results. The results of the previous study showed that the audit committee, the independent board of commissioners and CSR did not significantly influence the value of the company, while the board of directors affected the value of the company (Wardoyo, 2013). On the other hand, another study showed contradictory findings that independent commissioners, institutional ownership, audit committees, and CSR disclosure partially have a significant effect on firm value (Widyasari, 2013). Purbopangestu (2014) shows that managerial ownership and independent commissioners influence the disclosure of CSR. Once again, the results of these studies contradict the study that was conducted by Paramita (2014), which show that the independent commissioners and audit committees have no effect on CSR disclosure. Research that related to good governance and disclosure of corporate social responsibility is a topic that is so interesting to study. This is because of the contradictory findings by prior researchers.

GCG and CSR research in the mining sector is very necessary, because this sectors' business operational activities impacts directly on the use of natural resources which will have a direct impact on the environment. Mining sector companies can have two negative impacts on the environment for operational activities carried out. First, the use of process inputs, namely unbalanced exploitation of natural resources, and the threat of overusing natural resources, so that they cannot be renewed. Second, the impact of the production process, namely the presence of air and water pollution, as well as the creation of company waste, such as the rest of the production process containing hazardous chemicals that can pollute the surrounding environment (Hadi, 2011).

\section{LITERATURE REVIEW AND HYPOTHESES}

\section{Good Corporate Governance (GCG) and Firm Value}

Agency theory emphasizes the importance of company owners (shareholders) to hand over company management to professional staff (agents) who understand more about running their business (Sutedi, 2012). From this view, it can be said that GCG can be used as a system that controls the company management and minimizes the conflicts of interest in the company, so that the investors can be positively perceived. GCG is also a process and structure that will be used to direct and manage the accountability of the corporate and business. The main objective of the implementation of GCG is to optimize the value of the company while taking care of the interests of the stakeholders.

The mechanism of GCG in a company is expected to maximise the supervisory function in company management so that each step taken by the company is in line with the company's objectives. According to Purbopangestu (2014), if an institution is able to carry out its supervisory function to its full function, the value of a company can increases. 
Similarly, Wardoyo and Veronica (2013) stated that GCG will bring positive and significant results to the company value. If there are many companies that implemented GCG well, it will increase the company's value. Plus, investors will also consider whether the company that they will invest in is implementing GCG or not.

\section{Hypothesis 1: Good Corporate Governance (GCG) influences Firm Value}

\section{Good Corporate Governance (GCG) and Corporate Social Responsibility (CSR)}

The implementation of Good Corporate Social Responsibility (CSR) is inseparable from the internal and external party role of the company. Every business person must understand well the good corporate governance principle in order for them to apply its application in the company's operational activities. GCG also can help to increase the trust and confidence of the stakeholders and other external parties towards the company.

Hasung Jang in Wahyudi and Azheri (2008) stated that the issues surrounding GCG are not only related to business and economic issues, but also related to social and political aspects (aspects of CSR). GCG concept can encourage the accountability and the transparency of the company. Wahyudi and Azheri (2008) also asserted that GCG and CSR have a very close relation each other. Both are interrelated by a similar central point; it is about the responsibility of the stakeholders. The differences are GCG gives more focus on the benefits of the stakeholders, where the company should create a value-added from the products and deeds of the stakeholders, and maintain the continuity of the value-added created. Based on the concept of creating value-added for the stakeholders, the principle of responsibility in GCG will create the idea of corporate social responsibility (CSR) or the role of the company in realizing its social responsibility.

The better a company in implementing GCG mechanism, the broader the scope of their CSR (Sembiring, 2005). Implementation of GCG will ease the management process and also make monitoring of processes become more effective. Purbopangestu (2014) stated that the level of oversight of management could force management to disclose social information by the company.

\section{Hypothesis 2: Good Corporate Governance (GCG) influences the Corporate Social Responsibility (CSR).}

\section{Disclosure Corporate Social Responsibility (CSR) and Firm Value}

According to Hadi (2014), a stakeholder is a party (both internal and external) who have a relationship (both influential and influenced), and are directly or indirectly impacted by the company. Therefore, stakeholders have the right to obtain information about the activities of the company during a certain period that is able to influence or be influenced by various decisions, taxation and company operations. CSR activities 
carried out by the company are a form of responsibility and care for the environment and local society. The application of CSR is expected to encourage companies to be more ethical in carrying out their operational activities so that it does not have a negative impact on the environment and surrounding communities, so that the continuity of the company's operations can be guaranteed. According to Purbopangestu (2014), the more companies disclose items in CSR and the better the quality of disclosure, the higher the value of the company. Consistently, Purbopangestu (2014) states that CSR disclosure has a positive and significant effect on company value.

\section{Hypothesis 3: Good Corporate Governance (GCG) influences disclosure of Corporate Social Responsibility (CSR).}

\section{METHODOLOGY}

The type of this research is explanatory research with a quantitative approach. The population is all mining companies listed on the Indonesia Stock Exchange (IDX) between 2014- 2017, an amount of 40 companies. The sample for this study was taken based on the purposive method with the criteria: 1) mining sector companies listed on the Stock Exchange; 2) published financial statements in full for three consecutive years (2014-2017); 3) included information regarding GCG and CSR disclosures in that period. Based on these criteria, there are 13 companies sampled. Data sources were taken from the IDX's online database (Wardoyo, 2013). There are three latent variables in this study, namely: (1) Good Corporate Governance (GCG) with 5 (five) indicators; (2) Corporate Social Responsibility (CSR) with 6 (six) indicators; (3) Firm Value or company value with 2 (two) indicators. To test the hypothesis, this study used Partial Least Square (PLS) as an analysis technique. There are 2 (two) stages of measurement in this analysis: measuring the outer model (how latent variables are formed or reflected by indicators) and inner models (explaining the relationship between latent variables) (Widarjono, 2015).

The measurement or outer model will be evaluated by the convergent validity (the value of loading factor), it should be greater than 0.5 (Hair et al, 2014). Whereas for structural or inner model will be tested by evaluating the value of $\mathrm{R}$-square $\left(\mathrm{R}^{2}\right)$ and predictive-relevance $\left(\mathrm{Q}^{2}\right)$ (Yamin, 2011). To test the model fit with the original data, it uses four fit measurement model average path coefficient (APC) and average block variance inflation factor (AVIF) (Ghozali, 2014). The hypotheses that are already developed are tested with a level of confidence of $95 \%$.

\section{RESULTS AND DISCUSSION}

Variable of Good Corporation Governance (GCG) is measured with five formative indicators, which are the board of directors (DD), the board of commissioners (PDKI), audit committee (KA), institutional ownership (KI), and managerial ownership (KM). Variable Corporate Social Responsibility Disclosure (CSR) is measured by six indicators, namely indicators of the Economy (EC), Environment (EN), Employment (LA), Human Rights (HR), Society (SO), and Product Responsibility (PR). The 
company value variable is measured by three formative indicators, namely Price to Book Value (PBV) and Tobin's Q (TBQ).

Table 1. Value of outer loading variable GCG, CSR and Firm Value

\begin{tabular}{|l|c|c|l|}
\hline & $\begin{array}{l}\text { Outer } \\
\text { Loading }\end{array}$ & p-value & \multicolumn{1}{|c|}{ Conclusion } \\
\hline X1.1_DD & 0,451 & 0,017 & Do not meet the validity \\
\hline X1.2_PDKI & $-0,106$ & 0,510 & Do not meet the validity \\
\hline X1.3_KA & 0,053 & 0,844 & Do not meet the validity \\
\hline X1.4_KI & $-0,241$ & 0,335 & Do not meet the validity \\
\hline X1.5_KM & 0,948 & 0,000 & Meet the validity \\
\hline Y1.1_EC & 0,220 & 0,524 & Need further analysis \\
\hline Y1.2_EN & 0,516 & 0,256 & Meet the validity \\
\hline Y1.3_LA & 0,792 & 0,218 & Meet the validity \\
\hline Y1.4_HR & 0,550 & 0,249 & Meet the validity \\
\hline Y1.5_SO & 0,239 & 0,468 & Need further analysis \\
\hline Y1.6_PR & 0,780 & 0,216 & Meet the validity \\
\hline Y2.1_PBV & 1,000 & 0,000 & Meet the validity \\
\hline Y1.6_PR & 0,810 & 0,000 & Meet the validity \\
\hline
\end{tabular}

Based on table 1, it can be seen the loading factor value and p-value from each indicator. The indicators that passed the model test (outer loading is greater than 0.5) could be used to the next step. There are: managerial ownership (KM), Environment (EN), Employment (LA), Human Rights (HR), Product Responsibility (PR), Price to Book Value (PBV) and Tobin's Q (TBQ).

Table 2 below is the results of testing the inner model fit which is also a hypothesis test that has been formulated. This test is to know the relationship between variables GCG, CSR and FV.

Table 2. Value inner model fit

\begin{tabular}{|c|c|l|c|c|}
\hline Hypotheses & $\begin{array}{c}\text { Independent } \\
\text { Variable }\end{array}$ & $\begin{array}{c}\text { Dependent } \\
\text { Variable }\end{array}$ & P- Values & Conclusion \\
\hline H1 & GCG (X1) & FV (Y2) & 0,000 & Accepted \\
\hline H2 & GCG (X1) & CSRD (Y1) & 0,000 & Accepted \\
\hline H3 & CSRD (Y1) & FV (Y2) & 0,875 & Not-Accepted \\
\hline
\end{tabular}

Based on table 2, it has a positive and significant effect of GCG on firm value, the effect of GCG on CSR disclosure is negative and significant, and there is no significant effect of CSR disclosure on firm value. The complete outer and inner models can be seen in the figure below. Goodness of fit structural models in PLS analysis are predictive relevance values $\left(\mathrm{Q}^{2}\right)$. The value is calculated based on the $\mathrm{R}^{2}$ value of each endogenous variable is as follows: 0.74224 or $74.224 \%$. 


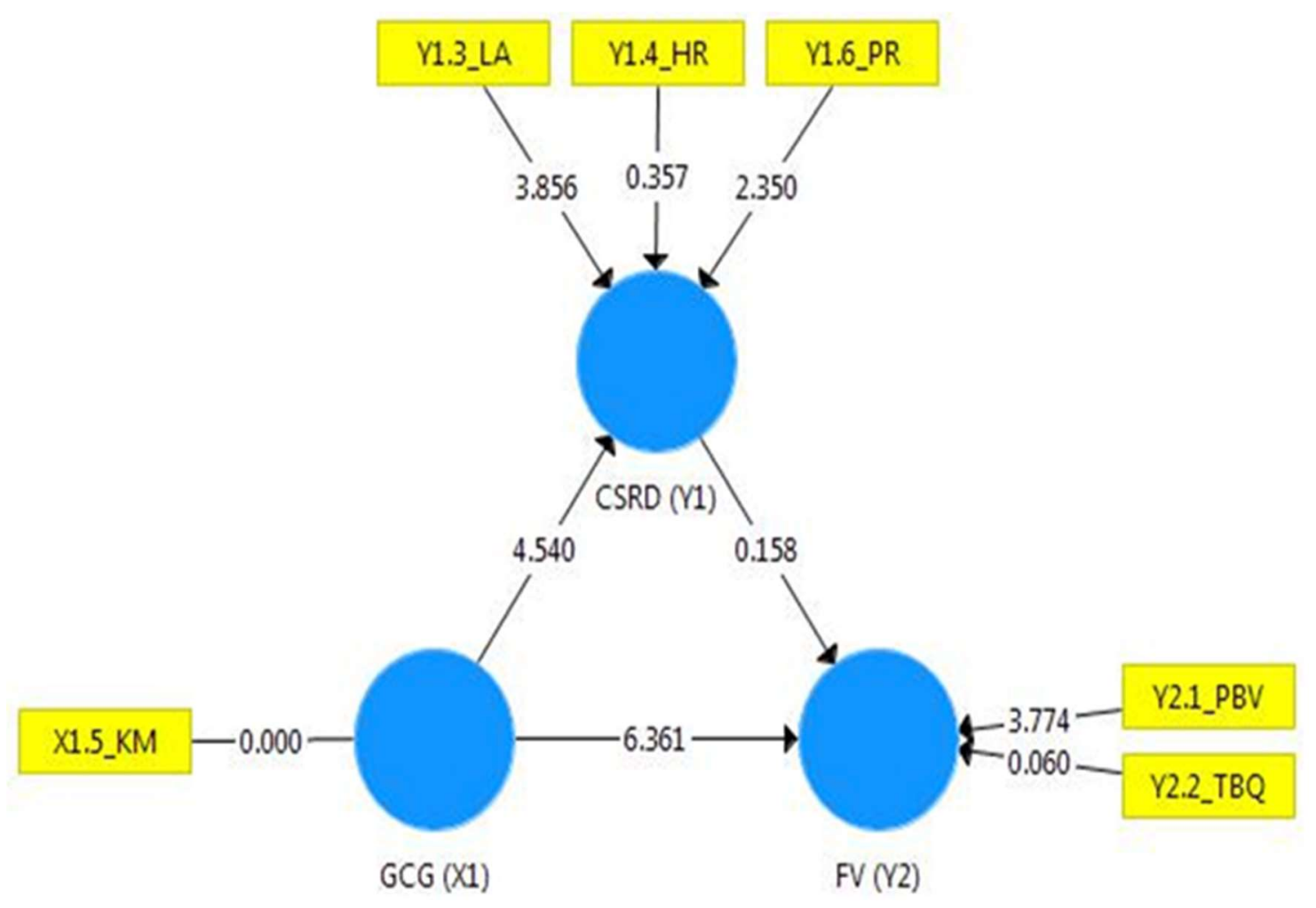

Figure 1. Outer and Inner Research Model

\section{Discussion}

Based on the results of the study, it can be concluded that Good Corporate Governance (GCG) has a positive and significant effect on firm value. GCG values are formed by indicators of the board of directors and managerial ownership, meaning that the better the board of directors and the greater the managerial ownership, the better the management of the company to increase the value of the company. This shows that investors or markets give a higher valuation to companies that implement GCG.

This research is in line with agency theory in minimizing conflicts of interest between managers and owners by implementing a supervisory mechanism for the company. The oversight mechanism can be carried out with the existence of a board of directors and managerial ownership, so as to foster a sense of belonging and responsibility to manage the company. Good company management can increase company value

Based on the results of the study it can be concluded that Good Corporate Governance (GCG) significantly influences the disclosure of Corporate Social Responsibility (CSR). CSR disclosure is the implementation of the principle of GCG responsibility to the corporate social environment, so that if the application of GCG is higher than CSR disclosure will be high as well (Paramita, 2014). Based on the annual report of the sample companies in 2014, it was a difficult time for the coal industry companies due to falling international coal commodity prices. The ban on the export of raw minerals and restrictions on coal imports by the Chinese government, and a coal supply that exceeds 
demand are several factors that have caused the coal industry in Indonesia to remain depressed. To be able to get around this, the company implemented operational cost efficiency (Wahyudi, 2008). This condition makes the management of mining companies, especially coal, to make cost efficiency in all aspects of operations to minimize the impact of reduced revenue, including to streamline the costs of corporate social responsibility. The results of this study support the results of the study, which showed that GCG had a significant negative effect on CSR disclosure (GRI, 2013).

\section{CONCLUSION}

It can be concluded that the disclosure of Corporate Social Responsibility (CSR) does not significantly affect the value of the company. Based on stakeholder theory, CSR disclosure is a company's effort to provide benefits for all stakeholders to achieve company goals. CSR disclosure can be considered by investors before investing their capital, but the results of the study indicate that investors do not respond positively to CSR disclosures that have been made by the company. Based on the average calculation of company value with PBV and Tobin's Q indicators in descriptive analysis shows that in 2015, the average value of the mining sector companies decreased when compared with the previous year, this is because the company's share price in 2015 also decreased, so the company does not implement its CSR.

\section{REFERENCES}

Gerianta Wirawan Yasa, I. (2013). Pengaruh Corporate Social Responsinility Pada Kinerja Keuangan Perusahaan Dan Implikasinya Terhadap Nilai Perusahaan. EJurnal Akuntansi, 4(2), 388-405. Retrieved from https://ojs.unud.ac.id/index.php/Akuntansi/article/view/6235

Global Reporting Initiative. (2013). Reporting Principles and Standard Disclosures. https://www.globalreporting.org/resourcelibrary/GRIG4-Part1-Reporting-Principles-andStandard-Disclosures.pdf

Ghozali, I. \& Latan, H. (2014). Partial Least Square Concepts, Methods and Applications Using the WarpPLS4.0 Program. Universitas Diponegoro, Semarang.

Hadi, Nor. (2011). Corporate Social Responsibility. Graha Ilmu, Yogyakarta.

Hair J. F., GTM Hult, C Ringle, and M Sarstedt (2014). A Primer on Partial Least Squares Structural Equation Modelling. Sage, Thousand Oaks.

Husnan, S. (2006). Teori dan Penerapan (Keputusan Jangka Panjang), $4^{\text {th }}$ ed. BPFE, Yogyakarta.

IDX. (2018). Indonesia Stock Exchange, Annual Report IDX.

Komite Nasional Kebijakan Governance. (2006). Pedoman Umum Good Corporate Governance, accessed on 23 December 2017.

Paramita, Andinia, (2014). Pengaruh Karakteristik Corporate Governance terhadap Luas Pengungkapan Corporate Social Responsibility. Diponegoro Journal of Accounting, 3(1), 1-15. https://ejournal3.undip.ac.id/index.php/accounting/article/view/6014

Purbopangestu, H., \& Subowo, S. (2014). Pengaruh Good Corporate Governance Terhadap Nilai Perusahaan Dengan Corporate Social Responsibility Sebagai Variabel Intervening. Accounting Analysis Journal, 3(3), 321- 333 https://doi.org/10.15294/aaj.v3i3.4202 
Sembiring, Eddy Rismanda. (2005). Karakteristik Perusahaan dan Pengungkapan Tanggung Jawab Sosial: Study Empiris pada Perusahaan yang Tercatat di Bursa Efek Jakarta, Simposium Nasional Akuntansi VII, Solo.

https://scholar.google.co.id/citations?user=7FjNfxUAAAAJ\&hl=id\#d=gs_md_cit $\underline{\mathrm{a}-}$

$\overline{\mathrm{d} \& \mathrm{u}=} \% 2 \mathrm{Fcitations} \% 3 \mathrm{Fview}$ op $\% 3 \mathrm{Dview}$ citation $\% 26 \mathrm{hl} \% 3 \mathrm{Did} \% 26 \mathrm{user} \% 3 \mathrm{D} 7 \mathrm{Fj}$ NfxUAAAAJ\%26citation for view\%3D7FjNfxUAAAAJ\%3Ad1gkVwhDpl0C\% 26 tzom $\% 3 \mathrm{D}-420$

Sutedi, Adrian. (2012). Good Corporate Governance. Sinar Grafika, Jakarta,

Wahyudi, Isa \& Azheri, Busyra. (2008). Corporate Social Responsibility: Prinsip, Pengaturan dan Implementasi. In-Trans Publishing, Malang.

Wardoyo, Veronica \& Martina,. (2013). Pengaruh Good Corporate Governance,

Corporate Social Responsibility dan Kinerja Keuangan terhadap Nilai Perusahaan. Jurnal Dinamika Manajemen. 4(2). 132-149

https://journal.unnes.ac.id/nju/index.php/jdm/article/view/2757/2823

Widarjono, Agus. (2015). Analisis Multivariate Terapan dengan Program SPSS, AMOS dan SMARTPLS. UPP STIM YKPN, Yogyakarta.

Widyasari, Nita Ayu. (2013). Pengaruh Good Corporate Governance (GCG) dan Pengungkapan Corporate Social Responsibility (CSR) terhadap Nilai Perusahaan. Jurnal Administrasi Bisnis (JAB),26(1), 1-10. http://administrasibisnis.studentjournal.ub.ac.id/index.php/jab/article/view/1021/1 $\underline{204}$

Yamin, S. \& Kurniawan, H. (2011). New Generation Processing Data with Partial Least Square Path Modeling. Salemba Infotek, Jakarta.

Zakarsyi, Moh \& Wahyudin. (2008). Good Corporate Governance: Pada Badan Usaha Manufaktur, Perbankan dan Jasa Keuangan Lainnya. Alfabeta, Bandung. 